\title{
Berbagai Dampak Hukuman (Punishment) dalam Pendidikan Terhadap Peserta Didik
}

\author{
Susmita Suharjo, Farid Pribadi \\ Sosiologi, Universitas Negeri Surabaya \\ Jl. Ketintang, Ketintang, Kec. Gayungan, Kota Surabaya, Jawa Timur \\ E-mail: susmitasuharjo17@gmail.com
}

\begin{abstract}
Article Info
Abstract

Received November 2021

Accepted November 2021

Published November 2021

Keywords:

Educational tools, punishment, and student

All humans are obliged to be educated. The objective of the subject of education is to improve the quality of oneself in order to become a complete person. In achieving that goal, education has tools to support its smooth running. One of the educational tools punishment which is punishment, has a profound impact on learners. The punishment in education is the punishment given to the learner aimed at edifying the offending learner. After the sentencing, the impact of the learner, the impact of each learner varied, to which in the study, researchers tried to dig up information on the impact of the punishment on the learner by using literature and secondary data, that is, data from previously existing sources such as journal articles, books, and scripts. Then the data was qualitatively analyzed using the miles and hubermans' methods. Analysis has resulted in some effect on learners. The effects are positive and dam impact.
\end{abstract}

\begin{abstract}
Abstrak : Semua manusia wajib untuk berpendidikan. Tujuan pokok pendidikan adalah dapat meningkatkan kualitas diri agar menjadi manusia yang seutuhnya. Dalam mencapai tujuan tersebut, pendidikan memiliki alat-alat sebagai pendukung dalam kelancaran prosesnya. Salah satu alat pendidikan yakni hukuman (punishment) yang mana alat pendidikan tersebut, memiliki pengaruh yang besar terhadap peserta didik. Hukuman dalam pendidikan merupakan hukuman yang diberikan kepada peserta didik yang bertujuan memperbaiki akhlak peserta didik yang melanggar tersebut. Setelah diberikan hukuman, kemudian muncul dampak dari si peserta didik, dampak setiap peserta didik berbeda-beda, untuk itu dalam penelitian ini, peneliti mencoba menggali informasi tentang dampak hukuman bagi peserta didik dengan menggunakan metode kajian literatur serta data sekunder, yakni data yang berasal dari sumber-sumber yang sudah ada sebelumnya seperti artikel jurnal, buku, maupun skripsi. Kemudian data-data dianalisis secara kualitatif menggunakan metode Miles and Huberman. Setelah dianalisis maka dihasilkan beberapa dampak hukuman terhadap peserta didik. Dampaknya berupa dampak positif dan dampak negatif. Beberapa diantaranya seperti adanya rasa ingin membalas dendam kepada si pemberi hukuman (pendidik), peserta didik yang semakin pandai dalam menyembunyikan kesalahan, menimbulkan rasa jera. Hukuman juga berdampak pada motivasi belajar peserta didik, setelah diberikan hukuman tidak jarang pesrta didik semakin semangat belajar dan memperbaiki akhlaknya. Hukuman yang diberikan juga berpengaruh pada semakin displinnya peserta didik terhadap larangan.
\end{abstract}

Kata Kunci: Alat-alat pendidikan, Hukuman, dan Peserta didik

C2021 Jurusan Ilmu Pendidikan, FKIP Universitas Lampung 


\section{PENDAHULUAN}

Semua manusia memiliki hak bersekolah dari sekolah dasar hingga perguruan tinggi. Semua manusia berkewajiban untuk berpendidikan, meskipun belum mampu sekolah formal hingga perguruaan tinggi. Pendidikan juga diatur dalam peraturan negara Indonesia, pendidikan diatur dalam Undang-Undang No.20 Tahun 2003, berisi Sistem Pendidikan Nasional yang berbunyi bahwa "pendidikan adalah usaha sadar dan terencana untuk mewujudkan suasana belajar dan proses pembelajaran agar peserta didik secara aktif mengembangkan potensi dirinya untuk memiliki kekuatan spiritual keagamaan, pengendalian diri, kepribadian, kecerdasan, akhlak mulia, serta keterampilan yang diperlukan dirinya, masyarakat, bangsa, dan negara".

Pendidikan merupakan bagian dari kehidupan yang mana pendidikan berfungsi untuk memperluas wawasan manusia, melatih manusia untuk berpikir lebih dalam ketika menghadapi sesuatu sehingga tidak hanya berpikir dangkal. Pendidikan dapat diperoleh dari proses kehidupan sendiri, kehidupan orang lain atau pengalaman orang lain, lingkungan sekitar, dan sekolah sebagai suatu instansi pendidikan. Pelaksanaan pendidikan bukan hanya mengajarkan mata pelajaran saja, namun juga menanamkan nilai-nilai karakter yang diharapkan bisa memberi kontribusi selain kecerdasan juga kontribusi moral yang memiliki value terhadap masyarakat, bangsa, dan negara kedepannya hingga tujuan dan fungsi pendidikan Indonesia yang telah diatur di UndangUndang No.20 Tahun 2003 dapat tercapai.

Fungsi pendidikan ialah melenyapkan semua sumber-sumber derita rakyat yang berasal dari kebodohan serta keterbelakangan, sejalan dengan fungsi pendidikan nasional Indonesia yang menyatakan jika pendidikan nasional memiliki fungsi untuk mengembangkan potensi serta menciptakan karakter peradaban bangsa yang bermoral dalam usaha mencerdaskan kehidupan bangsa (Sujana, 2019). Tujuan pokok pendidikan adalah dapat meningkatkan kualitas diri agar menjadi manusia yang seutuhnya. Dalam mencapai tujuan tersebut, pendidikan memiliki alat-alat sebagai pendukung dalam kelancaran prosesnya. Alat pendidikan ialah usaha pendidik yang bertujuan untuk melakukan tugas-tugas yang mendidik. Penerapan alat-alat pendidikan tidak hanya berbicara tentang teknisnya saja, namun juga 
berhubungan dengan si pendidik sebagai pribadi utama yang menjalankan proses pendidikan dan tanggung jawabnya dan peserta didik. Alat-alat pendidikan sendiri diantaranya ialah pembiasaan dan pengawasan, perintah dan larangan, serta ganjaran (reward) dan hukuman (punishment).

Dalam proses pendidikan, dampak dari hukuman (punishment) jauh lebih besar daripada dampak dari perlakuan alat-alat pendidikan yang lainnya. Tidak semua orang dapat melakukan hukuman, hal ini karena hak dalam menghukum hanya boleh dilakukan oleh orang-orang yang memiliki fungsi khusus seperti hakim, orang tua, dan guru. Cara-cara seorang pendidik saat memberikan hukuman pun berbeda-beda, maka berbeda-beda pula hasil nya. Berhasil atau tidaknya suatu hukuman (punishment) yang diberikan tergantung kepribadian pendidik, kepribadian peserta didik, cara yang digunakan saat memberikan hukuman, suasana ketika memberi hukuman, serta hubungan antara pendidik dan peserta didiknya.

Tujuan dari pemberian hukuman (punishment) dalam konteks pendidikan selalu mengarah ke arah yang baik, yakni untuk memperbaiki kepribadian peserta didik, namun dalam kenyataan hasilnya tidak semua bisa sesuai dengan apa yang diharapkan dan juga akibat atau dampak dari hukuman yang diberikan memiliki respon yang berbeda-beda dari setiap peserta didik. Oleh karena itu, tujuan dari penelitian ini adalah untuk mengetahui Berbagai Dampak Hukuman (Punishment) Dalam Pendidikan Terhadap Peserta Didik.

\section{METODE}

\section{Desain penelitian}

Penelitian ini menggunakan metode kajian literatur. Penelitian ini menggunakan data sekunder, yakni data yang berasal dari sumber-sumber yang sudah ada sebelumnya..

\section{Instrumen penelitian}

Data sekunder diperoleh dari pengumpulan maupun pengolahan data berupa studi dokumentasi seperti, artikel ilmiah, jurnal, skripsi, dan buku yang dipublikasikan secara online seperti e-journal maupun dipublikasikan sumber yang lain (Hasan, 2009). 


\section{Analisis data}

Data yang diperoleh kemudian dianalisis secara kualitatif menggunakan metode Miles and Huberman. Analisis data dilakukan empat tahap, yakni reduksi data, verifikasi, penyajian data, serta penarikan kesimpulan (Sugiyono, 2015).

\section{HASIL DAN PEMBAHASAN}

Dalam undang-undang Nomor 20 Tahun 2003 tentang Sistem Pendidikan Nasional menyatakan bahwa,

"peserta didik adalah anggota masyarakat yang berusaha mengembangkan potensi diri melalui proses pembelajaran yang tersedia pada jalur, jenjang, dan jenis pendidikan tertentu".

Masih dalam rumusan undang-undang Nomor 20 Tahun 2003 pasal 1 yang mengandung arti dari pendidikan, menyatakan bahwa,

"Pendidikan adalah usaha sadar dan terencana untuk mewujudkan suasana belajar dan proses pembelajaran agar peserta didik secara aktif mengembangkan potensi dirinya untuk memiliki kekuatan spiritual keagamaan, pengendalian diri, kepribadian, kecerdasan, akhlak mulia, serta keterampilan yang diperlukan dirinya, masyarakat, bangsa dan negara".

Berdasarkan isi dari undang-undang tersebut, terdapat batasan setidaknya terdapat tiga pokok utama yang dimuat di dalamnya, yakni pertama; usaha yang sadar serta sudah direncanakan, kedua; usaha merealisasikan suasana pembelajaran agar potensi peserta didik dapat berkembang, ketiga; mempunyai nilai spiritual keagamaan, kepribadian, kecerdasan, moral, kontrol diri, serta keterampilan yang dibutuhkan diri, lingkungan sosial, bangsa juga negara. Tiga pokok pemikiran tersebut dijadikan sebagai rambu-rambu dalam menyelenggarakan proses pendidikan nasional, meskipun untuk hasil akhirnya masih belum dipastikan sesuai ekspektasi (Triyono, 2019).

Terdapat tiga jalur pendidikan, yakni pendidikan informal (keluarga), pendidikan non-formal (masyarakat), dan pendidikan formal (sekolah). Pendidikan informal dilakukan dalam lingkup keluarga. Indikator dari pendidikan informal seringkali dihubungkan dengan kemandirian belajar, pihak yang terlibat 'tidak secara sadar' mereka saling berinteraksi dan saling 
intervensi. Sejalan dengan pendapat Lengrand (1984) yang menyatakan bahwa, pendidikan informal jika dikaitkan dengan pendekatan kesadaran maka tujuan dari pihak-pihak yang terlibat di dalam pendidikan informal mencoba menempatkan proses pendidikan informal yang mana salah satu pihak yang terlibat, tidak menyadari tujuan pendidikan yang diberikan. Maknanya, pendidikan informal seringkali salah satu pihaknya tidak menyadari jika pihak lain yang berinteraksi dengan dia sedang memberikan arahan atau pembelajaran.

Biasanya yang menyadari hanya si pendidik. Misalnya, seorang ibu yang menyuruh anaknya membersihkan tempat tidurnya, mungkin si anak akan merasa tidak ada makna didalam tindakan tersebut karena membersihkan tempat tidur bisa dilkukan ibu saja, namun si ibu memiliki maksud agar si anak punya jiwa yang disiplin dan rapi. Definisi pendidikan informal ialah segala jenis aktifitas yang berkaitan dengan pemahaman, pengetahuan, maupun kecakapan yang berlangsung diluar kurikulum pembelajaran yang melembaga. Beberapa hal yang mendasari pendidikan informal yakni, tujuan atau makna, isi, cara serta proses perolehannya, durasi waktu, evaluasi hasil, serta aplikasi dimana hal-hal itu ditentukan individu yang terlibat dalam proses pendidikan informal tanpa dibutuhkannya seorang pemimpin dari lembaga (Sudiapermana, 2009).

Pendidikan nonformal atau pendidikan yang dilakukan di masyarakat. Konsep dari pendidikan nonformal sendiri ialah konsep pendidikan serta pembelajaran yang didasarkan pada masyarakat yang memiliki tujuan supaya masyarakat yang tidak mampu menikmati pendidikan formal dapat mendapatkan ilmu di pendidikan nonformal, dengan harapan supaya mampu mengelolah dan meningkatkan kehidupannya diranah apapun. Peran masyarakat sebagai sasaran pendidikan informal bisa dilihat dari partisipasi mereka dalam melaksanakan program-program yang berkaitan dengan mengasah kemampuan, keterampilan, serta dapat meningkatkan kualitas dirinya (Miradj, 2014).

Pendidikan formal yang dilakukan di sekolah Pendidikan ini dilakukan dengan sistematis dan terkontrol. Sekolah merupakan jenis dari pendidikan formal yang terstruktur, pendidikan formal dilakukan mulai dari pendidikan taman kanak-kanak hingga pendidikan di perguruan tinggi yang dianggap 
sebagai "kasta" tertinggi dalam sekolah formal. Dalam proses pendidikan secara formal, terdapat macam-macam alat pendidikan, dimana alat-alat pendidikan tersebut digunakan sebagai penunjang tercapainya cita-cita pendidikan.

Dalam buku dengan judul Ilmu Pendidikan Teoretis dan Praktis karya Purwanto (2014) menjelaskan bahwa, alat-alat pendidikan diantaranya adalah pembiasaan dan pengawasan, perintah dan larangan, serta ganjaran (reward) dan hukuman (punishment). Semua alat-alat pendidikan tersebut memiliki syarat tertentu dalam melaksanakannya, artinya semua alat-alat pendidikan tidak hanya membicarakan teknis saja namun juga aturan bagaimana melaksanakannya, karena dampak dari alat-alat pendidikan dapat menjadi buruk atau baik tergantung dari si pemberi hukuman (pendidik), yang menerima hukuman, ikatan diantara keduanya, cara menghukum, serta suasana saat pemberlakuan alat-alat pendidikan tersebut.

Keberhasilan dari pemberlakuan alat-alat pendidikan tidak ada rumus atau buku kamusnya. Dikutip dari (Tangkuman, 2015), hukuman (punishment) adalah suatu yang kurang atau tidak menyenangkan dan tak diinginkan sebagai respon dari suatu perilaku tertentu. Hukuman (punishment) dilaksanakan jika telah terdapat bukti adanya penyimpangan. Definisi hukuman dalam sekolah menurut (Imron, 2012) ialah, suatu sanksi yang ditujukan untuk anak atau siswa yang telah melaksanakan suatu pelanggaran terhadap aturan yang sudah disepakati sebelumnya.

Hukuman menurut Martin (2003) ialah penderitaan yang diberikan kepada seseorang karena mereka sudah melakukan pelanggaran terhadap hukum atau aturan. Dalam bahasa sehari-hari, masyarakat memaknai hukuman sebagai pemberian sanksi. Sedangkan dalam Hurlock (1990) menyatakan jika hukuman adalah penjatuhan siksaan kepada seseorang yang telah melakukan pelanggaran sebagai balasannya. Pelanggaran maupun penyimpangan dianggap sebagai tindakan yang tidak berhasil dalam penyesuaian diri dengan kehendak atau ketentuan dalam masyarakat atau suatu kelompok tertentu. Perilaku melanggar atau menyimpang menurut James W. Van der Zander dalam Hisyam, (2018) menyatakan jika pelanggaran atau penyimpangan merupakan perilaku yang tercela yang dianggap keluar batas toleransi sebagian besar masyarakat atau suatu kelompok tertentu dan 
pelanggaran atau penyimpangan tersebut dilakukan oleh pihak individu ataupun sejumlah orang.

Dalam Anggita (2021) salah satu penyebab dari perilaku menyimpang ialah gagalnya proses sosialisasi dikeluarga maupun masyarakat (peran keluarga dalam proses sosialisasi dapat direalisasikan dengan menanamkan nilai serta norma pada anak sejak dini). Penyimpangan ataupun perilaku melanggar dapat diminimalisir ketika pendidik (guru) dan orang tua bekerjasama dengan baik dalam mendidik anak di sekolah dan juga di rumah.

Tujuan dari pemberlakuan hukuman (punishment) ialah untuk mengedukasi anak atau siswa agar muncul suatu kesadaran bertanggungjawab terhadap perilaku yang sudah dilakukan. Hukuman (punishment) ialah tindakan yang dilakukan dengan sadar oleh si pemberi hukuman kepada orang yang telah melakukan pelanggaran. Hukuman bersifat baik secara lahir batin bagi penerima hukuman, karena hukuman diberikan kepada orang yang kondisinya ada di bawah si penghukum. Tindakan memberikan hukuman ialah bagian dari suatu tanggungjawab yang bermaksud untuk mendidik orang lain yang melakukan pelanggaran dan berkewajiban melindunginya (Ahmadi, 1991).

Hukuman merupakan tindakan terakhir yang diberikan kepada anak karena telah melakukan pelanggaran. Artinya, hukuman dilakukan jika telah diberikan peringatan dan teguran yang baik tapi tidak berubah ke arah yang lebih baik, maka cara terakhir ialah diberikan hukuman. Hal tersebut agar anak menyadari pelanggaran yang dilakukan (Langa, 2014). Semua tindakan pelanggaran pasti memiliki resiko dalam mempertanggungjawabkan. Seorang anak atau peserta didik harus belajar bertanggungjawab atas pelanggaran yang mereka lakukan.

Lewat hukuman yang diberikan, diharapkan banyak nilai yang dipetik dan tertanam dalam diri anak atau peserta didik, seperti nilai tanggungjawab, disiplin, serta sikap untuk lebih berhati-hati. Pemberian hukuman juga diharapkan supaya anak tidak bertindak melanggar terhadap aturan yang sudah disepakati dengan penuh kesadaran (Indrakusuma, 1973). Hukuman juga dapat dikatakan sebagai penderitaan yang sengaja diberikan oleh seseorang yang berhak, sesudah adanya pelanggaran, kesalahan, atau kejahatan yang dilakukan orang lain dengan sengaja atau sadar. 
Terdapat beberapa teori hukuman. Teori pertama yakni teori pembalasan atau teori yang menyatakan jika hukuman diberikan karena ingin membalas dendam atas pelanggaran yang dilaksanakan orang lain sehingga hukuman bertujuan agar memenuhi rasa puas. Akibatnya, sebagain besar masyarakat memiliki pemikiran jika satu-satunya hukuman yang pas dan dianggap layak diberikan kepada orang yang telah "merusak kehidupan" adalah merusak kehidupan si pelaku dan kekerasan harus dilakukan untuk itu (Hudson, 2003).

Teori pembalasan memberikan hukuman kepada pelaku sesuai dengan tingkat kejahatan yang dilakukan dan teori pembalasan tidaklah cocok jika digunakan sebagai hukuman dalam pendidikan. Teori pencegahan atau perlindungan. Teori ini menyatakan jika hukuman bukan sebagai balas dendam atas pelanggaran atau kejahatan, namun sebagai upaya yang dapat melindungi masyarakat agar terhindar dari tindakan yang tidak benar. Dalam (Hudson, 2003), Bentham sebagai tokoh teori ini menyatakan jika perlu adanya pembeda antara mencegah seseorang agar tidak melakukan kejahatan (prevensi umum) dengan mencegah seseorang agar tidak melakukan kejahatan yang sudah pernah dilakukannya dahulu (prevensi khusus).

Kemudian teori perbaikan. Teori perbaikan bertujuan untuk mereformasi pelanggar dan mengarahkan kepada hal yang benar supaya menjadi masyarakat yang mentaati aturan, Si pelaku diberikan dukungan agar memperbaiki perilakunya (Lippman, 2010). Hukuman ini dianggap sebagai hukuman yang tepat untuk pendidikan, karena bertujuan memeperbaiki si pelanggar atau pelaku supaya menjadi pribadi yang lebih baik lagi secara lahir dan batin dan hukuman seperti ini tidak membutuhkan kekerasan. Kemudian terdapat teori menakut-nakuti, teori ini berartikan hukuman untuk membentuk perasaan takut melakukan tindakan yang tidak benar. Tujuan teori menakut-nakuti dibedakan menjadi tiga, yaitu tujuan individual, publik, serta tujuan jangka panjang.

Tujuan individual memiliki arti supaya pelanggar atau si pelaku jera jika hendak melakukan pelanggaran lagi, tujuan publik berartikan supaya masyarakat punya rasa takut untuk melakukan pelanggaran atau tindakan kriminal. Tujuan jangka panjang bermaksud supaya masyarakat mampu memelihara dan mempertahankan keajegan terhadap nilai dari hukuman 
(Handoko, 2019). Teori terakhir yakni teori ganti kerugian, pada teori ini digunakan untuk mengganti kerugian yang dialami oleh korban akibat tindakan kejahatan si pelanggar. Hukuman ganti rugi sering diterapkan pada masyarakat dan pemerintah.

Teori hukuman ganti rugi tidak dianjurkan bagi hukuman dalam proses pendidikan karena, dengan diberikan hukuman ganti rugi, si peserta didik akan mempunyai pikiran jika kesalahan dan dosanya sudah terbayarkan dan menjadikan si peserta didik tidak bersalah dikemudian hari (Purwanto, 2014). Teori-teori di atas masih memiliki kekurangan jika diterapkan dalam hukuman pada proses pendidikan, karena teori-teori di atas masih condong ke satu aspek saja. Pada dasarnya hukuman dalam proses pendidikan memiliki makna untuk memperbaiki tindakan atau perilaku peserta didik ke arah yang baik.

Dalam konteks pendidikan, dampak dari hukuman jauh lebih besar daripada dampak yang disebabkan oleh pemberian ganjaran (reward). Memberikan hukuman dilakukan dengan tidak bebas oleh siapapun, artinya hukuman hanya boleh diberikan oleh seseorang yang memiliki hak dan wewenang dalam menghukum seperti guru, orang tua, hakim, dan sebagainya. Dalam melakukan tindakan menghukum haruslah diberikan kontrol, baik oleh peraturan dalam sekolah atau masyarakat yang telah disepakati sebelumnya ataupun undang-undang negara (Purwanto, 2014).

Menurut (William Stern dalam Purwanto, 2014), membedakan tiga macam hukuman yang sesuai dengan tingkat perkembangan anak-anak yang menerima hukuman, yakni pertama; hukuman asosiatif, dimana biasanya seorang anak akan menghindari perbuatan yang kurang baik untuk menghindari hukuman, kedua; hukuman logis, hukuman logis diterapkan anakanak yang cukup dewasa yang mana mereka tau jika hukuman yang diberikan adalah akibat logis dari tidak baiknya tindakannya sendiri, ketiga; hukuman normatif, bermaksud untuk memperbaiki nilai moral anak-anak atau peserta didik karena telah melanggar norma etika seperti berbohong dan mencuri.

Menurut M. Ngalim Purwanto dalam (Saipullah, 2019), hukuman juga dibagi kedalam hukuman alam dan hukuman yang disengaja. Hukuman alam sendiri dianjurkan oleh J.J. Rousseau dengan alasan anak-anak dilahirkan dengan keadaan bersih tanpa dosa, yang membuat noda dan penyimpangan itu lingkungannya sendiri, untuk itu Rousseau memberikan anjuran agar anak- 
anak dididik menurut alam demikian berlaku untuk menghukumnya, biarkan saja alam yang memberikan hukuman. Namun, pendapat ini tidak bisa diterima sepenuhnya, hal itu karena hukuman alam dipandang dalam segi pendidikan sendiri dianggap tidak menghukum secara mendidik, artinya hukuman alam tidak memberikan pengetahuan bahwa tindakan ini benar atau salah, menjadikan anak-anak tidak tau nilai dan norma yang benar seperti apa. Hukuman alam terkadang bersifat membahayakan. Kemudian hukuman yang disengaja, yakni hukuman yang berlawanan dengan hukuman alam. Hukuman yang disengaja diberikan dengan memiliki tujuan dan disengaja.

Dalam setiap alat-alat pendidikan, selalu memiliki dampak dan manfaat tersendiri. Hal tersebut juga berlaku dalam salah satu alat pendidikan yakni hukuman, yang mana hukuman ini dampaknya lebih daripada dampak dari ganjaran atau reward. Setiap individu dalam menghadapi atau menerima dampak dari hukuman pasti berbeda-beda. Perbedaan tersebut dikarenakan beberapa faktor. Dalam memberikan hukuman dipendidikan, terdapat beberapa syarat dalam melaksanakannya, yaitu pertama; setiap hukuman yang diberikan harus bisa dipertanggung jawabkan, artinya hukuman tidak diperbolehkan dilakukan sewenang-wenang meskipun dilakukan oleh orang tua atau guru, kedua; hukuman harus bersifat memperbaiki, memiliki nilai yang mendidik, ketiga; hukuman yang diberikan bukan bersifat mengancam atau bertujuan untuk membalas dendam, keempat; waktu memberikan hukuman bukanlah saat sedang suasana marah, hal tersebut mencegah terjadinya lepas kontrol dan ketidak adilan dalam memeberikan hukuman, kelima; memberikan hukuman harus dalam keadaan sadar dan telah dipertimbangkan, keenam; tidak menghukum secara fisik, karena melanggar perikemanusiaan yang bersifat aniaya, ketujuh; memberikan hukuman jangan sampai memutuskan hubungan baik antara si penghukum (pendidik) dan yang dihukum (peserta didik), maka dari itu perlu adanya kesadaran diantara kedua pihak, kedelapan; berhubungan dengan point sebelumnya, si pendidik diharapkan punya kesanggupan untuk meminta maaf setelah memberikan hukumannya dan setelah si peserta didik menyadari kesalahannya.

Setelah pendidik memberikan hukuman, maka kemudian akan menimbulkan dampak maupun respon dari peserta didik. Berbagai respon peserta didik terhadap diberlakukannya hukuman dalam proses pendidikan 
memuat pro dan kontra. Meskipun terdapat perbedaan terhadap penerimaan akan hal tersebut, hukuman yang bersifat mendidik mempunyai makna dan maksud yang sama yakni untuk memperbaiki perilaku peserta didiknya, meskipun terkadang hasilnya belum sesuai dengan yang diharapkan. Berbagai dampak maupun respon peserta didik terhadap hukuman dalam (Purwanto, 2014) diantaranya yaitu, pertama; peserta didik atau anak menjadi semakin pandai dalam menyembunyikan pelanggaran yang dilakukan, hal ini biasanya terjadi karena terbiasa dihukum yang bersifat menakut-nakuti, kedua; memunculkan rasa balas dendam terhadap si penghukum, biasanya terjadi karena saat memberikan hukuman suasanya sedang marah atau tidak kondisional, ketiga; menyebabkan si pelanggar kehilangan rasa bersalah, hal tersebut karena si pelanggar berpikir jika kesalahannya telah ditebus oleh hukuman yang diberikan, keempat; membuat si pelanggar menjadi lebih baik, ini biasanya karena hukuman yang diberikan bersifat noratif, kelima; si pelanggar memperbaiki tingkah lakunya, seperti saat ditegur untuk tidak berbicara saja dalam kelas saat jam pelajaran, keenam; memberikan rasa jera terhadap si pelanggar, meskipun hukuman yang diberikan bukan bersifat fisik, namun seringkali peserta didik malu dihukum jika ketauan oleh temantemannya.

Ayu (2017), menyebutkan bahwa penerapan hukuman juga berdampak dalam mendisiplinkan peserta didik, hal tersebut dibuktikan dengan hasil penelitian yang dilakukan di salah satu SMA di Surabaya, ternyata 81,64\% peserta didik menyetujui diberlakukannya hukuman jika melanggar kedisiplinan, karena mereka melihat kenyataan dalam sekolah, jika diberlakukan hukuman maka, peserta didik lebih bisa disiplin seperti peserti berkurangnya peserta didik yang terlambat masuk sekolah. Sejalan dengan hasil penelitian Ardi (2012), bahwa terdapat korelasi antara pemberian hukuman di sekolah dengan kedisiplinan peserta didik dalam belajar dan pengaruh diantara keduanya sangat kuat.

Hukuman dalam pendidikan juga dapat berdampak pada Self Management (pengelolaan diri) peserta didik, seperti dalam (Firmansyah, 2019) dikatakan jika setelah diberikan hukuman edukatif, peserta didik semakin berhati-hati dalam berperilaku, lebih sopan, peserta didik lebih aktif, tidak ramai dalam kelas ketika pelajaran berlangsung, dan mampu menghargai 
waktu seperti datang sekolah dan masuk kelas tepat waktu, mengisi waktu kosong dengan kegiatan yang bermanfaat. Hukuman juga dapat berpengaruh dalam meningkatkan motivasi belajar peserta didik, seperti observasi yang dilakukan Darmayanti, dkk,(2020) dikatakan jika hukuman dapat membuat peserta didik merasa malu dan jera setelah diberi hukuman karena meninggalkan kelas atau meninggalkan jam pelajaran kemudian mereka diberikan hukuman. Mereka merasa tertinggal pelajaran oleh teman-temannya dan merasa takut jika tidak mengerti, maka mereka meningkatkan belajarnya meskipun mengejar materi di rumah, mereka juga takut jika tidak naik kelas maka dari itu mereka berusaha untuk belajar sendiri di rumah dan bertanya jika disekolah.

\section{KESIMPULAN}

Pendidikan memiliki peran penting dalam kehidupan manusia. Pendidikan dapat diperoleh dari manapun, secara teori pendidikan dapat dibagi menjadi tiga yakni pendidikan informal (keluarga), pendidikan nonformal (masyarakat), dan pendidikan formal (sekolah). Pendidikan memiliki tujuan, dalam mencapai tujuan pendidikan terdapat alat-alat pendidikan yang membantu dalam mencapai tujuan pendidikan sendiri. Alat-alat pendidikan diantaranya ialah pembiasaan dan pengawasan, perintah dan larangan, serta ganjaran (reward) dan hukuman (punishment).

Setiap alat-alat pendidikan pasti memiliki syarat dalam menerapkannya. Setelah menerapkan alat-alat pendidikan, pasti akan memiliki dampak atau respon dari si pelanggar atau si pelaku. Salah satu alat pendidikan yang memiliki dampak besar terhadap perilaku peserta didik adalah hukuman (punishment). Hukuman dalam hal ini ialah hukuman yang bersifat mendidik bukan merusak, mengancam, atau membalas dendam. Hukuman tidak diberikan sembarang orang, hanya individu yang memiliki hak dalam menghukum saja seperti orang tua dan guru. Meskipun memiliki hak untuk menghukum jika peserta didik melakukan pelanggaran, menghukum harus terdapat control didalamnya. Setelah melakukan hukuman dampak atau respon yang diberikan peserta didik sangat beragam.

Beberapa dampak atau respon hukuman terhadap peserta didik berdampak positif, namun tidak jarang juga berdampak negatif. Beberapa 
diantaranya seperti adanya rasa ingin membalas dendam kepada si pemberi hukuman (pendidik), peserta didik yang semakin pandai dalam menyembunyikan kesalahan, menimbulkan rasa jera. Hukuman juga berdampak pada motivasi belajar peserta didik, setelah diberikan hukuman tidak jarang pesrta didik semakin semangat belajar dan memperbaiki akhlaknya. Hukuman yang diberikan juga berpengaruh pada semakin displinnya peserta didik terhadap larangan..

\section{DAFTAR PUSTAKA}

Anggita, Atikah Dewi. (2021). Analisis Faktor-Faktor yang Mempengaruhi Perilaku Menyimpang Pada Anak Usia Sekolah Dasar di SD Negeri Pleburan 03 Semarang.

Ahmadi, Abu. (1991). Ilmu Pendidikan . Dalam N. U. Abu Ahmadi (eds.), Ilmu Pendidikan. Jakarta: Rineka Cipta.

Ardi, M. (2012). Pengaruh Pemberian Hukuman Terhadap Disiplin Siswa Dalam Belajar (Penelitian Eksperimen di Kelas VIII Sekolah Menengah Pertama Negeri 1 Nanga Tebidah Kecamatan Kayan Hulu Kabupaten Sintang). EKSOS. 61-72.

Ayu, Intan Kususma. (2017). Respon Siswa Terhadap Pemberian Hukuman Pada Siswa Yang Melanggar Disiplin di SMA Kartika IV-3 Surabaya. Kajian Moral dan Kewarganegaraan: 272-285.

Darmayanti, Irma R. A.(2020). Implementasi Metode Hadiah dan Hukuman Dalam Meningkatkan Motivasi Belajar Siswa. Andragogi: 19-38.

Firmansyah, Deny. (2019). Peran Hukuman Edukatif Dalam Membentuk Self Management Siswa (Studi Kasus di Madrasah Diniyah Mambaul Hisan Kadipaten Babadan Ponorogo). Skripsi Strata 1. Ponorogo: Fakultas Tarbiyah dan Ilmu Keguruan Institut Agama Islam Negeri (IAIN) Ponorogo.

Handoko, Ary Prasetyo. (2019). Eksistensi Pidana Kebiri Kimia Ditinjau Dari Teori Tujuan Pemidanaan (Studi Atas Peraturan Pemerintah Pengganti Undang-Undang Nomor 1 Tahun 2016 Tentang Perubahan Kedua Atas Undang-Undang Nomor 23 Tahun 2002 Tentang Perlindungan Anak). Skripsi Strata 1. Yogyakarta: Fakultas Hukum Universitas Islam Indonesia.

Hasan, I. (2009). Analisis Data Penelitian dengan Statistik. Jakarta: Bumi Aksara.

Hisyam, C. J. (2018). Perilaku Menyimpang: Tinjauan Sosiologi. Jakarta: Bumi Aksara.

Hudson, B. A. (2003). Understanding Justice: An Introduction to Ideas, Prespectives and Controversies in Modern Penal Theory. Dalam B. A. Hudson, Understanding Justice: An Introduction to Ideas, Prespectives 
and Controversies in Modern Penal Theory . Philadelphia: Open University Press.

Hurlock, Elizabeth (1990). Perkembangan anak, terjemah. Med. Meitasari Tjandrasa. Jakarta: Erlangga.

Imron, A. (2012). Manajemen Peserta Didik Berbasis Sekolah. Jakarta: Bumi Aksara.

Indrakusuma, A. D. (1973). Pengantar Ilmu Pendidikan. Surabaya: Usaha Nasional.

Langa, C. (2014). Reward and Punishment Role in Teacher-Student Relationship From the Mentor's Prespective. Acta Didactica Napocensia: hal 7.

Lengrand, P. (1984). Pendidikan Sepanjang Hayat. Terjemah Lembaga Studi Ilmu-ilmu Kemasyarakatan. Jakarta: Gunung Agung.

Lippman, M. (2010). Contemporary Criminal Law: Concepts, Cases, and Controversies. London: SAGE Publications.

Martin, H. Manser. (2003). Oxford learner's Pocket Dictionary. New York: Oxford University Press.

Miradj, Safri. (2014). Pemberdayaan Masyarakat Miskin, Melalui Proses Pendidikan Nonformal, Upaya Meningkatkan Kesejahteraan Sosial di Kabupaten Halmahera Barat. Pendidikan dan Pemberdayaan Masyarakat: 101-112.

Purwanto, M. N. (2014). Ilmu Pendidikan Teoretis dan Praktis. Bandung: PT Remaja Rosdakarya.

Saipullah, Asep. (2019). Pengaruh Punishment Terhadap Hasil Belajar Siswa Pada Mata Pelajaran Hadits (Studi di Kelas VIII SMP Al-Mizan Cikole Pandeglang). Skripsi Strata 1. Banten: Fakultas Tarbiyah dan Keguruan Universitas Islam Negeri (UIN) Sultan Maulana Hasanuddin Banten.

Sudiapermana, E. (2009). Pendidikan Informal Reposisi, Pengakuan dan Penghargaan. Pendidikan Luar Sekolah.

Sugiyono. (2015). Metode Penelitian Pendidikan Pendekatan, Kuantitatif, Kualitatif, dan R\&D. Bandung: Alfabeta.

Sujana, I. W. (2019). Fungsi dan Tujuan Pendidikan Indonesia . Pendidikan Dasar.

Tangkuman, Kevin. (2015). Penilaian Kinerja, Reward, dan Punishment Terhadap Kinerja Karyawan Pada PT. Pertamina (Persero) Cabang Pemasaran Suluttenggo . EMBA: 884-895.

Triyono, U. (2019). Kepemimpinan Transformasional Dalam Pendidikan (Formal, Non Formal, dan Informal). Yogyakarta: Deepublish.

Undang-Undang Sitem Pendidikan Nasional [online] diakses 5 November 2021 (https://pmpk.kemdikbud.go.id/assets/docs/UU_2003_No_20__Sistem_Pendidikan_Nasional.pdf) 